\title{
Pseudo-patriotic Undertone of Unity Discourse in Nigeria's Print Media
}

\author{
Ahmed Tanimu Jibril ${ }^{a}$ \\ ajtanimu@basug.edu.ng \\ Bauchi State University, Nigeria \\ Afida Mohamad Ali \\ afida@upm.edu.my \\ Universiti Putra Malaysia, Malaysia \\ Zalina Mohamad Kasim \\ zalina_mk@upm.edu.my \\ Universiti Putra Malaysia, Malaysia \\ Chan Mei Yuit \\ cmy@upm.edu.my \\ Universiti Putra Malaysia, Malaysia
}

\begin{abstract}
The realisation of genuine national unity within its ethnically diverse society has always been the primary challenge facing Nigeria since its Independence in 1960. This study investigated the discursive recontextualisation of national unity through newspaper congratulatory announcements (NCAs) within Nigeria's ethnically diverse society, focusing on the pseudopatriotic undertones of the privately sponsored NCAs. Critical discourse analysis (CDA) and the agenda-setting theory informed the theoretical underpinning of the study. The data is drawn from four major dailies, covering the period between 2011 and 2016. Multimodal critical discourse analysis (MCDA) and the visual grammar (VG) are used as analytical methods to examine 97 privately sponsored NCAs. Dominant themes in the NCAs are highlighted along with the type of national unity projected in the NCAs. The analysis revealed that, in the name of promoting unity, private individuals and global conglomerates utilize pseudo acts to boost profits, enhance customer index, and construct their corporate image in the eyes of the ruling regimes and the general public in their host communities. It was also found that the envisioned future of the country as a united reality appears to contradict the common perception and lived experiences of the people. This study is meant to highlight the way certain ideologies are promoted and further interests are realised through the print media in the name of pseudo-patriotism. Further research may investigate comparable representations likely found in other newspaper genres as well as additional semiotic resources such as Nigeria's Civil War artefacts and monuments, statues, and other national symbols.
\end{abstract}

Keywords: Pseudo-patriotism; newspaper congratulatory announcements; unity; multimodal critical discourse analysis; Nigeria

\section{INTRODUCTION}

The values of diversity, teamwork and multi-cultural unity have been immensely utilised in television commercials and advertisements when it comes to Independence Day or National Day celebrations in countries all around the world. For example, Leo Burnett Malaysia, an advertising company, states that clients and advertisers continue to choose this theme to show how a multi-racial society that works together can be a strong catalyst in progressing as a

${ }^{a}$ Main author

${ }^{b}$ Corresponding author 
nation ('Commemorating the Merdeka Spirit of Unity', 2010). Malaysian companies such as Petronas, Tenaga Nasional Berhad, Nestle Malaysia, Digi Telecommunications and Axiata to name a few, have all joined the bandwagon in their Merdeka laudatory advertisements by instilling the spirit of being united and working together irrespective of the different races to build a better Malaysia. In India, Cadbury, the chocolate company, introduced the Unity bar on India's 2019 Independence Day, which had four different variations in one bar ranging from dark, blended, milk, and white. Although, it received its fair share of criticisms, promoting diversity was the principal motive behind this concept. The Unity Bar, according to Cadbury, reflects a unified India that is not divided by the caste system, a long-standing social and religious hierarchy that segregates race and class-based men (Wida, 2019). Unity in diversity can also be seen in HueRay Technology's congratulatory message to United Arab Emirates on its $45^{\text {th }}$ National Day with the slogan 'Spirit of the Union. UAE - A country that welcomes people from all cultures and communities'. As attested by Koch's (2019) study on corporate advertisements surrounding National Day holiday celebrations in Qatar and the United Arab Emirates (UAE), corporate actors around the world are regularly promoting scripts that make the 'country' central by drawing on and effectively generating themes that serve the interests of the particular nation and their own business interests.

Newspaper congratulatory announcements (NCAs) are contextualised within the noncommercial and the homely discourse category to accomplish what seems to be mostly the constructive personal desires of the addressee. It is also expected to sustain social balance as it focuses on the addressee's face needs. More so, the acts of congratulating strive to attain the addressee's 'positive face wants' in an attempt to construct and maintain healthy social rapport. In essence, NCAs are classified as one of the most important genres, although, it has not received the required attention from the research community. The focus of this study on the reproduction of unity discourse using the NCAs becomes much more pertinent as advertisements, especially the print ones, are believed to serve as the most conducive avenues where topical issues associated with societies and politics are invariably played out (Ademilokun \& Taiwo, 2013).

In post-independence Nigeria, the realisation of genuine national unity within this ethnically diverse society has always been the primary challenge facing the country (Odeyemi, 2014; Bourne, 2015; Solomon, 2015). The problem of disunity among Nigerians has been largely attributed to the decision of the British colonial rulers to amalgamate the northern and the southern protectorates in 1914 without any proper "roundtable agreement" between numerous ethnicities. The amalgamation has always been referred to as 'the mistake of 1914' (Odeyemi, 2014, pp. 93-94; Bourne, 2015). In addition, a number of sociopolitical factors are believed to have greatly contributed in polarising the Nigerian people alongside tribal, ethnic, religious and regional prejudices (Emmanuel, 2016). A large portion of the blame is always thrown at successive military incursions into the political scene (Falola \& Heaton, 2008; Odeyemi, 2014; Bourne, 2015) and the resurgence of secessionist movements in both the southeast and the south-south regions. Other factors include the Boko Haram insurgency in the northeast region, which is basically focused on carving out an Islamic caliphate from the Nigerian state (Bourne, 2015; Solomon, 2015; Monguno \& Bagu, 2017) as well as periodic sporadic ethno-religious disturbances (Adediji, 2016; Anyebe, 2017).

Typically, the business of promoting unity in multiethnic states is projected to be handled by the ruling establishments (Mohamed Salleh, 2013; Babatope, 2017; Ahmad Tajuddin, 2017). Most notably, the mainstream media in some countries are seen as 'progovernment' agencies which are geared toward serving the 'politically invested interests' of their proprietors (Wok \& Mohamed, 2017 cited in Suppiah et al., 2019, p. 138). Though, in some cases, people in such societies become hesitant in accepting certain government proposed policies as far as ethnic matters are concerned (Holman \& Arunachalam, 2015). This article is 
focused on investigating the way private individuals and corporate bodies strive to influence the hearts and minds of the masses by championing issues concerning national unity in Nigeria. While nation building often utilises the discourse of national unity as a rallying call, national unity, being essentially an 'imagined' state itself (Haag, 2010, p. 335), can be manipulated to achieve hidden agendas. As a concept associated with patriotism, social responsibility, civicmindedness, and all socially desirable traits, it is an ideal tool to be used to legitimise discursive actions (Stögner \& Wodak, 2016; Haag, 2010). What do these private individuals and corporate organisations participating in the grand discourse of national unity in Nigeria aim to achieve? Are they working to help the government in its efforts to forge stronger national unity? Or do they use socially acceptable actions to project pseudo-patriotism and, simultaneously, to achieve other personal or corporate interests? This concern stems from the fact that this type of promotion of unity is not a government policy or government directed ideology, at least not on the surface of discourse. Therefore, other possible opportunistic self-interests may be played out in the process of its construction (Mohamed Salleh, 2013; Holman \& Arunachalam, 2015). In the same vein, it is believed that other 'discursive patterns and strategies' could be deployed into the media discourses to get even much more radical views and 'positions' enacted and legitimised by interest parties (Alkhammash, 2020, p. 89).

\section{LITERATURE REVIEW}

Previous literature has evidenced the way multinational entities and private individuals and organisations utilise issues of national importance in specific contexts mostly for opportunistic and commercial agendas. For instance, Alkatiri (2014) examined the theme of pseudonationalism as seen in newspaper non-commercial advertisements sponsored by corporate establishments in Indonesia. The study sampled nationalistic and independence related advertisements from the Kompas, the Suara Merdeka newspapers and the Tempo magazine. The findings of the study indicated how Indonesian business corporations invested greatly in issues of national integration and worked out solutions for internal conflicts throughout the Indonesian Reformation era. The study concluded that despite all their contributions in maintaining social harmony and their commitment to social services, these moneymaking conglomerates appeared to use these avenues for other material gains such as re-establishing their economic relevance and promoting their products (Jibril, 2018).

The present study supposes that Alkatiri's (2014) study evidences how the promotion of unity is utilised as a platform where commercial and other interests are played out. It is argued that the study did not look critically at the way these foreign corporations operating in Indonesia could have taken advantage of the available discourse to control the hearts and minds of the public through participating in national matters. On the contrary, the study seems to agree with the text as it sees the pseudo acts of patriotism by the profit-making entities as a means through which ordinary people are reminded of the 'need for national unity' (Alkatiri, 2014, p. 169). The study also failed to see the actions of the foreign businesses from the perspective of how powerful institutions aim to control discourses and recontextualise social actions so that they can portray their own envisioned reality to the masses. Alkatiri's (2014) study could have asked that since the promotion of unity is usually the business of the government, why do these foreign companies get involved? Would these profit-making entities spend their money to sincerely promote nation building elsewhere? Or do they use this platform to project pseudo-patriotism and, at the same time, realise further self-interests?

More so, previous studies on unity discourse provide evidence on specific policies framed by the ruling establishments, which are intended to promote unity and nation building but, at the same time, such policies appear to have been rejected by some sections of society, as it is seen to be an attempt by political elites to control discourses and recontextualise social 
practices (Holman \& Arunachalam, 2015). For example, Holman and Arunachalam analysed 87 articles from the Singaporean Straits Times newspaper. In the country, the government adopts the strategy of development journalism, where the stakeholders are expected to actively participate in homeland building and focus on matters of national importance. The study found that Singapore's perceived multicultural integration, an outcome of ethnic nationalities intermingling with one another, may likely breakdown the moment individuals or groups feel wronged or maltreated. The study revealed that mediating issues related to multiculturalism and ethnicity by the government in Singapore is a deliberate effort to rationalise its involvements in racial matters. The media makes the multicultural and ethnic situations appear fragile so as to convince the general public about government's initiatives over multicultural harmony in the nation-state. The study has also revealed public unwillingness to accept specific government proposed alternative ethnic identities, most especially the idea of bi-racialism (Holman \& Arunachalam, 2015, pp. 501-509).

Multimodal print media contents, such as the NCAs, have always been perceived to be loaded with assortment of visual and non-visual semiotic elements meant to promote or realise specific sociocultural or political interests. It is hypothetically assumed that various semiotic resources do not get intermixed by coincidence in the language of advertising. In the first place, it is expected that such linguistic codes are employed to better convey the connotation and obtain the best advertising effect. Secondly, it is one of the major factors motivating language analysts and, more specifically, the CDA practitioners, to develop interest in deconstructing and unravelling the ideologies underneath such deliberate linguistic choices, most especially, in the textual composition of newspaper advertisements (Liu, 2019, p. 1523). Multimodality in discourses that are entrenched with ideas, values, and identities makes both the discourses and ideologies appear more convincing and dominating. Given their multimodal nature, the NCAs could also be employed to 'disseminate discourses' which communicate 'strategic ideological purposes' to the target audience (Machin, 2013, pp. 351-354).

\section{THEORETICAL FRAMEWORK}

This article is informed by the agenda-setting theory of media effects. The agenda-setting theory (AST) describes the influence of media contents which accord prominence to individuals, social establishments, and events, likewise in constructing social agendas (McCombs \& Shaw, 1972). The concept of the agenda-setting spells out how mass media relates to the public. The theory holds that the main concern of the media establishments is, by design, the main concern of the general public (McCombs \& Valenzuela, 2007) and that people's perception and approach to the world around them is constructed partly by media contents. The present study is focused on the discursive reproduction of unity in an ethnically diverse nation through privately sponsored newspaper congratulatory announcements (Jibril, Mohamad Ali, Kasim \& Chan, 2015). These are believed to have been injected with certain pseudo-patriotic elements designed by sponsors (Alkatiri, 2014). Newspaper contents and, specifically, advertisements, are essentially appropriate for critical examination as they may be diffused with political ideologies as every discourse is considered to be political in theory (Fairclough, 1995). Newspaper advertisements are also presumed to have the potential to influence people's opinion and to circulate information by employing both visual and nonvisual mechanisms (Kress \& van Leeuwen, 2006).

It is also expected that leading organisations do attempt to take control of the media by way of pseudo practices toget ideological and commercial benefits from the audience. In addition, the possibility of meddling with the media reportage in specified circumstances, to get social or political agendas either promoted or suppressed, is also advocated (Fairclough, 1995). Hence, it has now become paramount to investigate the type of the envisioned unity, 
which is proliferated by private individuals and corporate organisations in the NCAs, in the face of people's experienced reality as far as Nigeria's unity is concerned (Solomon, 2015; Bourne, 2015). For the multimodal nature of the NCAs and its vital role in getting intended communications across, it is believed that salience in the monomodal advertisements paved the way for the multimodal types to materialise. In the same vein, it is through the integration of the non-verbal to the predominantly verbal semiotic resources that salience is attained in a piece of advertisement. Therefore, salience has been very critical to the development of advertisement discourse for its ability to draw attention from the target audience and affect the textual structure of the advertisements in terms of meaning construction. Therefore, this study is framed by the agenda-setting theory of media studies, focused by Fairclough's critical discourse theory as widely practiced by social discourse analysts.

\section{METHODOLOGY}

Quantitative content analysis (QCA) is used to examine the discursive recontextualisation of national unity through NCAs within Nigeria's ethnically and culturally diverse society. QCA provides a deeper, interpretive dimension to the data by analyzing meanings, themes, and patterns in order to make inferences from them. The study sampled 97 NCAs drawn from Nigeria's four major dailies, comprising The Guardian, the Daily Trust, the Vanguard, and the Punch newspapers, while the period covered ranges between 2011 and 2016. The period between 2011 and 2015 was characterised by heightened political instability in the country. In 2011, for example, the country witnessed an unprecedented post elections violence, when the incumbent president at the time, Goodluck Jonathan, an Ijaw Christian from the South-south region, defeated the then presidential aspirant, Muhammadu Buhari, a Hausa-Fulani Muslim from the North. The situation even became much more precarious during the countdown to the 2015 general elections and afterwards, when the former was eventually unseated by the latter (Onimisi, 2015). The sampling focused on non-commercial NCAs, sponsored by private individuals, local and multinational companies operating within the Nigerian economy. QCA is regarded as one of the most appropriate and recognised methods for media content analysis, especially for advertisements. Texts can easily be summarised when given documents are analysed based on highlighted topics or issues.

Analytical tools from multimodal critical discourse analysis (MCDA) approach (Liu, 2019; Wang, 2014; Abousnnouga \& Machin, 2010a; Abousnnouga \& Machin, 2010b; Machin \& Mayr, 2012; Machin, 2013) and visual grammar (VG) (Kress \& van Leeuwen, 2006; Wang, 2014) are incorporated to analyse the dominant themes identified and the major issues highlighted within the NCAs. The tools highlight the version of national unity envisioned by private individuals and corporate bodies sponsoring the NCAs. MCDA represents the critical aspect integrated into the analysis of multimodal communications. This approach focusses on the way visual resources used in interactions interplay in transmitting power relations in discourses (Machin \& Mayr, 2012, pp. 7-10; Wang, 2014). Additionally, through the multimodal approach to texts, complex ideas and attitudes are communicated using diverse integrated semiotic resources. It is expected that multimodality provides the ground where discourses can be re-enacted, normalised and communicated outside their linguistic sphere (Machin, 2013, p. 348). VG is essential to analyse the NCAs as the present-day newspaper advertisements are mostly composed of visual and non-visual semiotic resources. Though entrenched within the multimodal theory, $\mathrm{VG}$ is more or less proposed to describe texts as well as document the patterns. This multimodal descriptive approach is designed towards a 'systematic analysis of (media) texts' (Machin \& Mayr, 2012, p. 2).

Kress and van Leeuwen's (2006) approach for visual communication presents a threedimensional system of meaning, which comprises the representational (ideational), the 
interactional (interpersonal) and the compositional (textual). The representational function of language manifests in its description, reflection, or interpretation of the world around us in terms of our individual or collective experiences of happenings. The interactive function represents the way language is employed to interact with people, enact and retain social relationships as well as influence other people's thoughts. In its own right, the compositional function is realised through the ability of language to turn a random list of sentences into a living passage. In so doing, spoken or written texts would be linked to everyday world affairs (Liu, 2019, pp. 1524-25). For the purpose of analysing the multimodal properties constituting the textual composition of the NCAs incorporated into the present study, a number of tools from the VG and the MCDA were utilised. Table 1 highlights and describes the multimodal tools/features deployed for analysis in this study.

TABLE 1. Visual Devices and Spatial Dimensions Examined in this Study*

\begin{tabular}{|c|c|c|c|}
\hline \multicolumn{4}{|c|}{ Multimodal Devices and Space Dimensions } \\
\hline Device & Interpretation & Device & Interpretation \\
\hline Plate & $\begin{array}{l}\text { Refers to the entire frame } \\
\text { of an announcement/ } \\
\text { advert }\end{array}$ & Centred & $\begin{array}{l}\text { The centred element in a } \\
\text { visual composition }\end{array}$ \\
\hline Composition & $\begin{array}{l}\text { Distribution of visual and } \\
\text { non-visual devices within } \\
\text { plate's spatial dimension }\end{array}$ & Margin & $\begin{array}{l}\text { The non-centred position in } \\
\text { composition dependent on the } \\
\text { salience of the centred } \\
\text { element }\end{array}$ \\
\hline Social distance & $\begin{array}{l}\text { Invisible social boundaries } \\
\text { determining distance kept } \\
\text { between interlocutors }\end{array}$ & Polarised & $\begin{array}{l}\text { Refers to the absence of a } \\
\text { centred element in a given } \\
\text { composition }\end{array}$ \\
\hline Involvement & Frontal angle shot & Circular & $\begin{array}{l}\text { Non-central components } \\
\text { positioned on top and beneath } \\
\text { the centre }\end{array}$ \\
\hline Horizontal angle & $\begin{array}{l}\text { Function of relationship } \\
\text { between both the frontal } \\
\text { levels of photographer and } \\
\text { that of the participant }\end{array}$ & Triptych & $\begin{array}{l}\text { A Margin-Centre-Margin } \\
\text { composition or a polarised } \\
\text { image with Centre mediating } \\
\text { Given and New or Ideal/Real }\end{array}$ \\
\hline Demand & $\begin{array}{l}\text { Participant's direct eye } \\
\text { contact with the viewer }\end{array}$ & Connection & $\begin{array}{l}\text { When elements are joined } \\
\text { together in a composition } \\
\text { without any framing device }\end{array}$ \\
\hline Offer & $\begin{array}{l}\text { Participant's absence of } \\
\text { direct visual contact with } \\
\text { the viewer }\end{array}$ & Disconnection & $\begin{array}{l}\text { When elements in a } \\
\text { composition are separated by } \\
\text { space and other features }\end{array}$ \\
\hline Intimate/Personal & $\begin{array}{l}\text { A close-up shot where head } \\
\text { and shoulders of the visual } \\
\text { participant appear }\end{array}$ & Mediator & $\begin{array}{l}\text { An element in a polarised } \\
\text { position mediating between } \\
\text { Given/New and Ideal/Real to } \\
\text { reconcile them in a way }\end{array}$ \\
\hline Reactional process & $\begin{array}{l}\text { Represents actions of } \\
\text { whether glancing, watching } \\
\text { or staring at the objects } \\
\text { being viewed }\end{array}$ & $\begin{array}{l}\text { Symbolic } \\
\text { process }\end{array}$ & $\begin{array}{l}\text { Does not represent narration } \\
\text { in content but symbolises } \\
\text { something related to a specific } \\
\text { cultural context }\end{array}$ \\
\hline Announcement & $\begin{array}{l}\text { Stands for the most salient } \\
\text { linguistic item, a word or a } \\
\text { phrase, mostly placed at the } \\
\text { topmost position in the } \\
\text { visual plate }\end{array}$ & Enhancer & $\begin{array}{l}\text { Refers to the linguistic } \\
\text { passage mostly placed below } \\
\text { the Announcement to enhance } \\
\text { and elaborate it. It usually } \\
\text { contains some persuasion }\end{array}$ \\
\hline Modality & $\begin{array}{l}\text { Stands for the degree of } \\
\text { credibility accorded to } \\
\text { visual representations as if } \\
\text { they are real or actually } \\
\text { exist or do not }\end{array}$ & Action process & $\begin{array}{l}\text { Any actions from the part of } \\
\text { participants (animate or } \\
\text { inanimate) towards a goal }\end{array}$ \\
\hline
\end{tabular}




\begin{tabular}{|c|c|c|c|}
\hline Impersonal & $\begin{array}{l}\text { A long shot where the } \\
\text { human figure covers about } \\
\text { half the height of the frame }\end{array}$ & Image act & $\begin{array}{l}\text { It is constituted with viewers' } \\
\text { eyes are looked into and } \\
\text { addressed directly by the } \\
\text { participants as 'you' }\end{array}$ \\
\hline Salience & $\begin{array}{l}\text { The level of attention } \\
\text { drawn to an element due to } \\
\text { its size, frontal positioning, } \\
\text { colour, clarity or quality }\end{array}$ & Detachment & Oblique angle shot \\
\hline Given & $\begin{array}{l}\text { The commonsense element } \\
\text { placed on the left hand side } \\
\text { of the composition }\end{array}$ & $\begin{array}{l}\text { Information } \\
\text { value }\end{array}$ & $\begin{array}{l}\text { Positioning of participants in } \\
\text { specific zones apportion them } \\
\text { certain informational value }\end{array}$ \\
\hline New & $\begin{array}{l}\text { The not-yet-known } \\
\text { element placed on the right } \\
\text { hand side of the } \\
\text { composition }\end{array}$ & Gaze & $\begin{array}{l}\text { A direct eye contact with } \\
\text { visual subject(s) which is } \\
\text { called 'demand' }\end{array}$ \\
\hline Ideal & $\begin{array}{l}\text { The idealised, most salient } \\
\text { element on the upper part } \\
\text { of the composition }\end{array}$ & Social & $\begin{array}{l}\text { A medium shot where subject } \\
\text { appears almost to his/her } \\
\text { knees }\end{array}$ \\
\hline Real & $\begin{array}{l}\text { The more specific and } \\
\text { practical element on the } \\
\text { bottom of the composition }\end{array}$ & Participants & $\begin{array}{l}\text { The visual and non-visual } \\
\text { elements depicted or } \\
\text { constituting a composition }\end{array}$ \\
\hline Anchorage & $\begin{array}{l}\text { An illustrative relationship } \\
\text { between text and image in a } \\
\text { visual frame, where both } \\
\text { devices complement each } \\
\text { other in meaning-making }\end{array}$ & Framing & $\begin{array}{l}\text { The use or non-use of framing } \\
\text { techniques to connect or } \\
\text { disconnect elements in plates, } \\
\text { implying they do not belong } \\
\text { together in some sense }\end{array}$ \\
\hline Zones & $\begin{array}{l}\text { The various angles in a } \\
\text { frame, i.e. centre/margin } \\
\text { left/right and top/bottom }\end{array}$ & Top/Bottom & $\begin{array}{l}\text { A polarised composition with } \\
\text { either the visual or non- } \\
\text { visuals placed one above the } \\
\text { other }\end{array}$ \\
\hline Height & $\begin{array}{l}\text { A meaning potential mostly } \\
\text { linked to monuments, } \\
\text { indicating the positioning } \\
\text { of a statue in relation to } \\
\text { viewer }\end{array}$ & Size & $\begin{array}{l}\text { A meaning potential in } \\
\text { monuments where symbolic } \\
\text { significance is usually } \\
\text { associated with its sizes }\end{array}$ \\
\hline Solidity & $\begin{array}{l}\text { The symbolic association } \\
\text { of monuments made of } \\
\text { solid materials with solid } \\
\text { character and reverence } \\
\text { compared to lighter items } \\
\text { which are prone symbolic } \\
\text { to vulnerability, weakness } \\
\text { and accessibility }\end{array}$ & Angularity & $\begin{array}{l}\text { Stands for shapes key to } \\
\text { meaning-making in } \\
\text { monuments such as curvature, } \\
\text { roundness, angularity which } \\
\text { may denote emotion, } \\
\text { smoothness, masculinity, } \\
\text { objectivity, fluidity or } \\
\text { harshness }\end{array}$ \\
\hline Recontextualisation & $\begin{array}{l}\text { The way social interactions } \\
\text { are represented and } \\
\text { transformed in the context } \\
\text { of another }\end{array}$ & Abstraction & $\begin{array}{l}\text { Involves the concealment of } \\
\text { actual processes, identities } \\
\text { and circumstances while } \\
\text { foregrounding the more } \\
\text { sensuous of the discursive } \\
\text { event }\end{array}$ \\
\hline Presences & $\begin{array}{l}\text { In recontextualisation, } \\
\text { attention is paid to the } \\
\text { presence of participants, } \\
\text { things, behaviours, goals } \\
\text { and values in social } \\
\text { interactions }\end{array}$ & Absences & $\begin{array}{l}\text { Social interactions are not } \\
\text { always fully presented. } \\
\text { Attention should always go to } \\
\text { elements that appeared to } \\
\text { have been excluded }\end{array}$ \\
\hline
\end{tabular}

*Sources: Kress \& van Leeuwen (2006); Wang (2014); Machin \& Mayr (2012); Abousnnouga \& Machin (2010a); Abousnnouga \& Machin (2010b) 


\section{RESULTS AND DISCUSSIONS}

The thematic analysis of the selected NCAs revealed five dominant themes. QCA was employed to determine the recurrent topics within the NCAs. The identified themes include promoting national unity through: i) peaceful coexistence; ii) patriotic values; iii) diversity; iv) nation building, and v) cultural diversity. Each dominant theme is hereby presented.

\section{PEACEFUL COEXISTENCE}

The construction of unity through peaceful coexistence was identified in the NCAs. Through the process of recontextualisation, the real social actors and events are transformed and reproduced by way of employing words and expressions that serve the values and purposes of the text in relation to the social context (Fairclough, 1995, p. 115). In Figure 1, the ideational or ideological meanings of the text and images in the visual plate on the left hand side appeared to be encoded in a metaphorical representation as symbolised by the three little girls. The discursive narrative of unity and harmonious coexistence is recontextualised by substituting the prevailing rivalry and antagonism characterising the relationship between Nigeria's major ethnic groups with an innocent childlike and full-of-life scenario. The sporadic acts of violence and reprisals which always resulted from political and ethno-religious conflicts in the country appeared to have been substituted with little toddlers painting one another with multiple colours, in a visible sense of innocence and accommodation. More so, the multiple colours used by the children could be substituting the multiple ways through which different ethnic and cultural groups in the country usually exchange blame and demonise one another. By replacing the normally aggressive adults with the naturally affectionate children in this discursive process, any reminders of ill-feelings and resentment appeared to have been muted. Evaluation is another process of recontextualisation normally realised through the sequence of events, according to their importance, objectives and principles, as arranged in the written expression: We are happy people... We are growing no matter the adversity, we will achieve greatness (see Machin, 2013, p. 353).

On the visual frame placed on the right hand side in Figure 1, the representational participants seemed to have been abstracted by way of identification. For example, the social actors are reproduced in a way to symbolise recognizably Nigeria's three major ethnic groups: Yoruba, Hausa/Fulani and Igbo. The process of evaluation seems to have been reflected in all three social actors' firm grip on the Nigerian flag and raising it above their heads. Their actions could be evaluated by way of modalities and personal pronouns as expressed in the non-visual text:

we will continue to serve our father land. (Machin, 2013, pp. 348-353) 


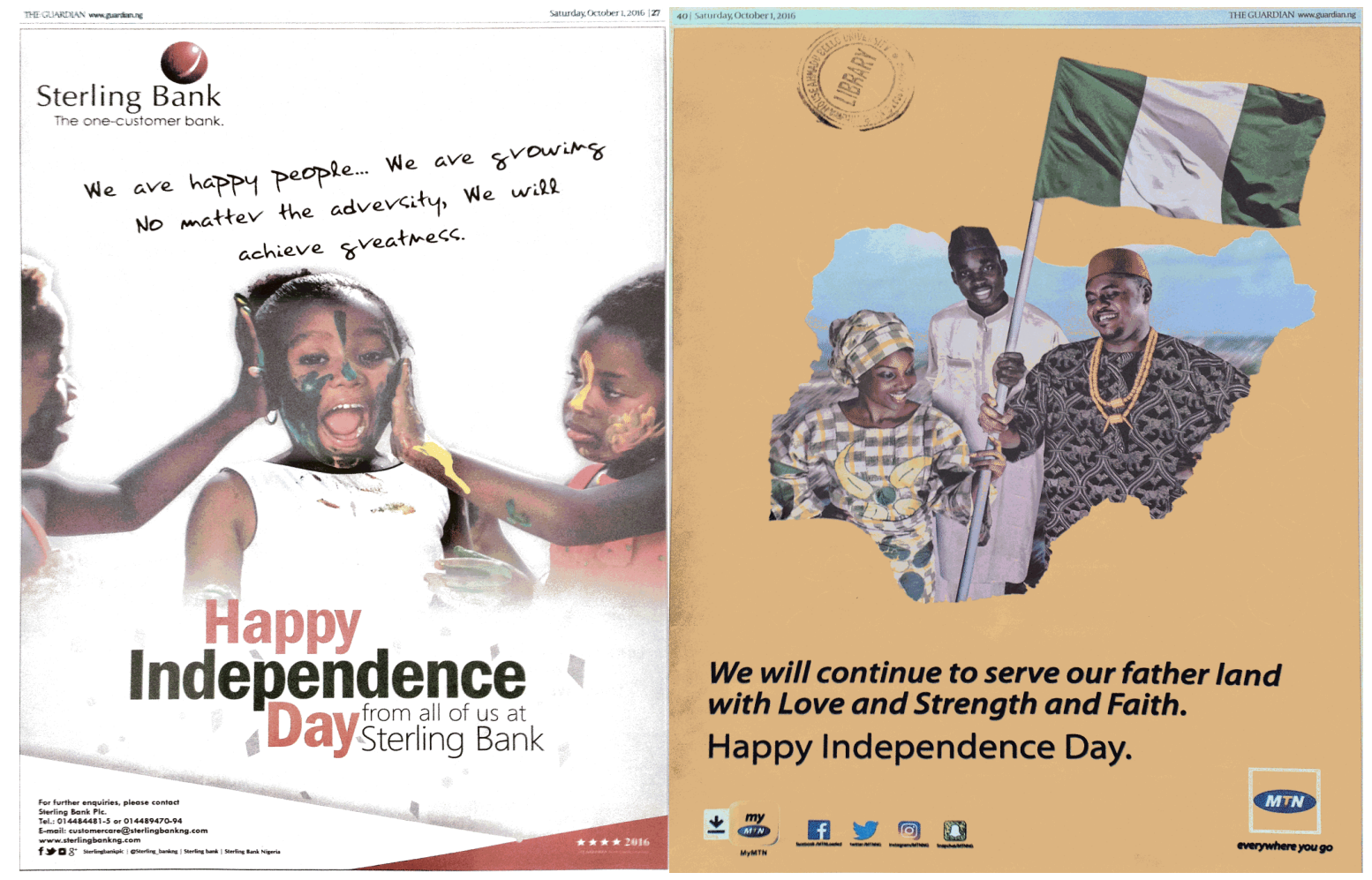

FIGURE 1. Depiction of normalisation of unity through peaceful coexistence (Left: The Guardian, Oct. 1, 2016, p. 27. Right: The Guardian, Oct. 1, 2016, p. 40)

\section{PATRIOTIC VALUES}

The construction of unity through patriotic values is another central theme constituted by the recurrent topics in the NCAs. The use of phrases such as:

\section{our beloved Nigeria, the resilient spirit of Nigeria, surviving against all odds, our} beloved fatherland

is another form of discursive transformation, where texts are used in promoting the values and purposes they were meant to serve in the wider social setting (Fairclough, 1995, p. 115). The visual plates in Figure 2 demonstrate the way patriotic values are employed to get unity discourse enacted, reproduced and normalised (Machin, 2013). In Figure 2, the visual image on the left-hand-side represents the discursive construction of unity through patriotism, which is realised through recontextualising the social actors and events. For example, the sequence of events implies the evaluation process, which can be seen in the car's wing mirror looking back, where the present is linked to the past, which is to the history where it all started. The written text on top of the visual plate stating that: A Nation with a resolve to Go Further appears to be complementing the image positioned below it. Using the image of a vehicle with a modern design could be suggesting a forward motion and shuttling into the envisioned future is reinforced by the perspective of the road with different sized letter fonts. The side mirror designed in the shape of Nigerian map, which reflects a black-and-white footage of the country's moment of Independence on October 1, 1960, symbolises the sequence of events in this social process. The image also speaks of a struggle, perseverance, selflessness as well as the sacrifices made by the founding fathers to see the liberation of a nation. The symbolic representation in the black-and-white footage may be suggesting that the most dignified way of protecting their legacy is through preserving the unity of the country. Interpersonally, both the Queen of England and Nigeria's first Prime Minister are visually placed in the position of 
offer, where the audience 'feels unacknowledged' and made to remain as a spectator without any interactions. By looking 'forward', not at the viewers, the social actors and the events, which are associated with the events of gaining political independence of a nation, appeared to have been connected with 'a different world', which is projected to be full of aspirations and visions (Abousnnouga \& Machin, 2010a, p. 144; see Abousnnouga \& Machin, 2010b, p. 228). Meanwhile, the vehicle races forwards, an image reinforced at the bottom with the alliterated slogan Ford, go further.

On the other end, the visual plate on the right hand side in Figure 2 symbolises the recontextualised social actors and the whole concept of patriotism in total 'abstractions'. The process appeared to have been actualised as the "social relations involved" in organising the visual frames in the form of the Nigerian Map as well as the actual 'production processes' are removed. That is to say, the people who could have done the arrangement and the way the whole process was carried out were concealed. Having done that, it is the most aesthetic stage of the manufacturing process, where a complete and excellently arranged visual frame, in the shape of the Nigerian Map, is foregrounded. Therefore, it is believed that genuine indications of ideological work are mostly found within these types of representations, where real processes, identities, and circumstance are abstracted (Machin, 2013, pp. 352). The actors, portrayed in the photo frames suggest family and activity centered on the national flag. Again, the configuration of portraits reinforces the unity through diversity theme. The written expression: No place like home serves as the most important non-visual text in the plate. The remaining written text below the Announcement serves as the enhancer, which elaborates it. Specifically, the non-visual segment stating: may our past feasts inspire us to even greater heights as we look forward to a more prosperous future appears to be expounding the current state of No place like home, which is envisioned by the announcers to be in good shape, as a better tomorrow is aspired for.

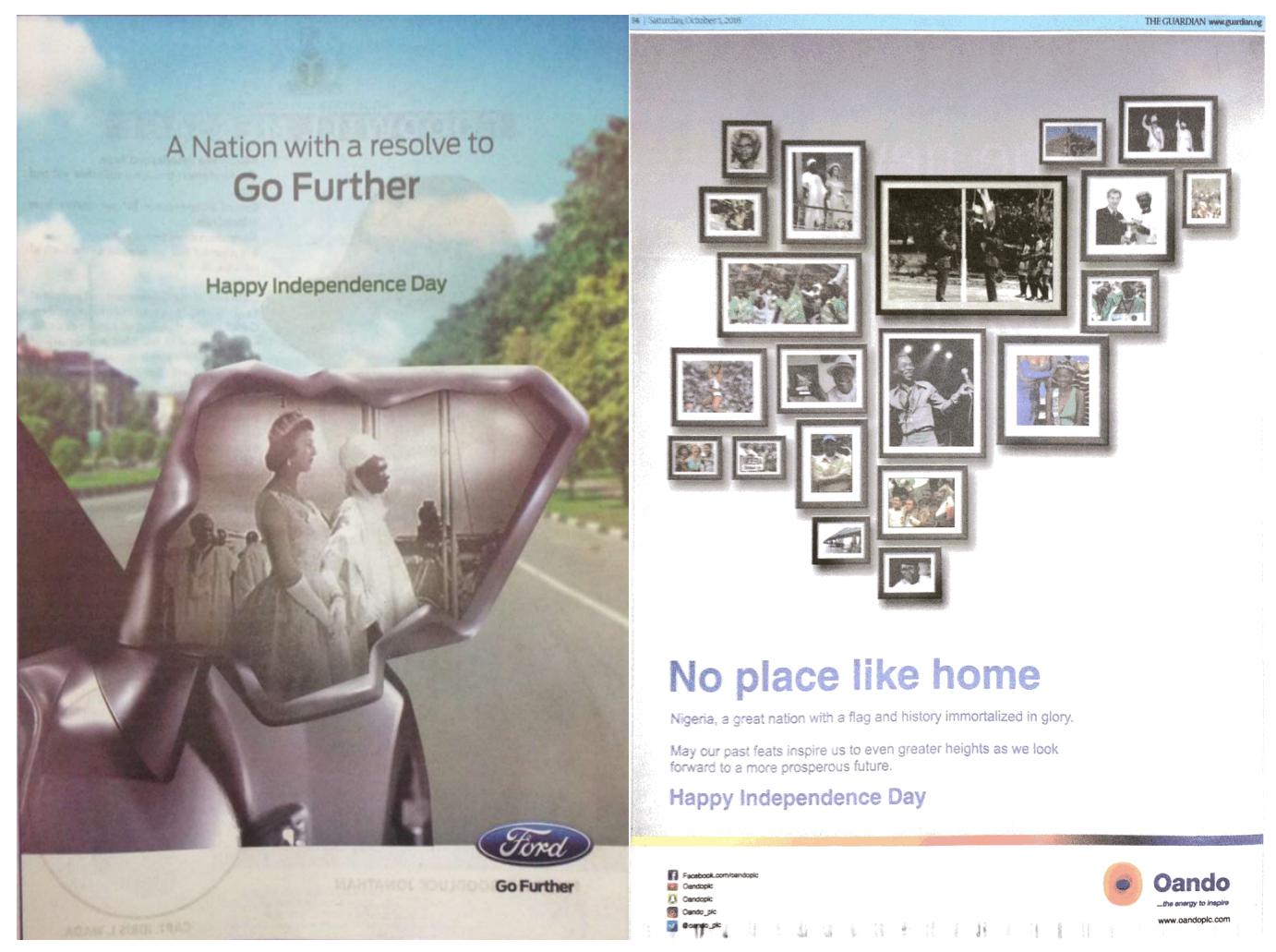

FIGURE 2. Re-enactment of the promotion of national unity through patriotic values (Left: Daily Trust, Oct. 1, 2013, p. 34. Right: The Guardian, Oct. 1, 2016, p. 14) 


\section{DIVERSITY}

The construction of unity through diversity has also been identified in the NCAs. Diversity is so essential a factor when it comes to matters of national unity (Holman \& Arunachalam, 2015). It is argued that the realisation of unity and national identities cannot be imagined if actual diversity is not tolerated and celebrated. These two concepts - unity and diversity - are not essentially antithetical, because elements of diversity could be traced and referred to even within national symbols and emblems. It is suggested that the broader concept of diversity should accommodate other categories, which include gender, race, age or sexuality, which are regularly excluded during discussions on cultural diversity, for instance (Haag, 2010, pp. 335). In Figure 3, the real social actors and events in the visual plate on the left hand side were recontextualised into a form of an erected heavy bronze-cast monuments, where a carved out Nigerian Map is raised above three figures, in an attempt to construct, naturalise and re-enact the concept of the nation through diversity and power of togetherness. Abousnnouga and Machin (2013) consider that discourses could be naturalised, reproduced and communicated through erected monuments engraved out of mountains or bronze-plated objects, mostly done using the olden methods. In Figure 3, both the social actors and the Nigerian Map were reproduced in that bronze-cast classical form, so it would imply some values related to the earth, timelessness, higher standards and fine civilisations. The discourse of unity in diversity among Nigerians is hereby naturalised and conveyed as a kind of classical, timeless, civilised and a smooth even artistic process (Machin, 2013, p. 350).

Usually, figures in monuments are normally depicted larger than the actual people or any represented elements. Still, the three figures raising the statue of the Nigerian Map in Figure 3 appear smaller compared to the map figure itself. Ideationally, the size of the map figure here seems to be associated with significance and power over the represented figures raising it. In other words, the metaphor of height, in opposition to the ground level, is employed at this point to signify the greater cause normally associated with nations, most especially, when they are compared to the ordinary citizens or masses. At the same time, the three figures raising the map statue are portrayed in a situation which symbolises humility before the nation, even with being representationally closer to her than the viewer (Abousnnouga \& Machin, 2010a, pp. 144-145). Generally, the height at which a statue is placed in relation to the audience is said to have some significant meaning potential. Height and bulk of the monument also imply strength of those raising up and supporting the nation. Apart from height and size, solidity is another meaning potential in monuments, which has some symbolic relations. For example, soldiers and most public monuments are usually made of solid materials not the transparent ones, as they are meant to symbolise solidity of character and to be revered not analysed. It is even suggested that using lighter materials would likely make the monuments appear so vulnerable and accessible before the audience (Abousnnouga \& Machin, 2010b, pp. 234-237).

On the right hand side in Figure 3, the visual frame represents the discursive reproduction of the concept of unity through diversity. The real social actors and events have been recontextualised in total abstraction. This textual transformation (Fairclough, 1995b, p. 115) seemed to have been realised by way of some presences and absences in the discursive process. For example, the symbolic presence of various anonymous hands held tight together is an attempt to recontextualise the abstract concept of unity in diversity by way of concrete demonstration of various hands held tight together. The unidentified hands appeared to have been added to normalise the representational concept of unity in diversity and made them look as if they are constructed by the private sponsors of the NCAs (Machin, 2013). Moreover, the absence of any human faces from the discursive process may have been done deliberately to suggest that unless all divisive tribal, religious, and social biases are eliminated, the most desired unity would never be realised. The Nigerian masses of different social classes, the 
Nigerian map or any other elements that may suggest any form of social incongruity has been replaced with a strip of the Nigerian Flag cutting across the visual frame. With this abstraction, the nation, Nigeria, and all its ethnic, religious, and sociopolitical complexities appeared to have been represented in total symbolism (Machin, 2013).

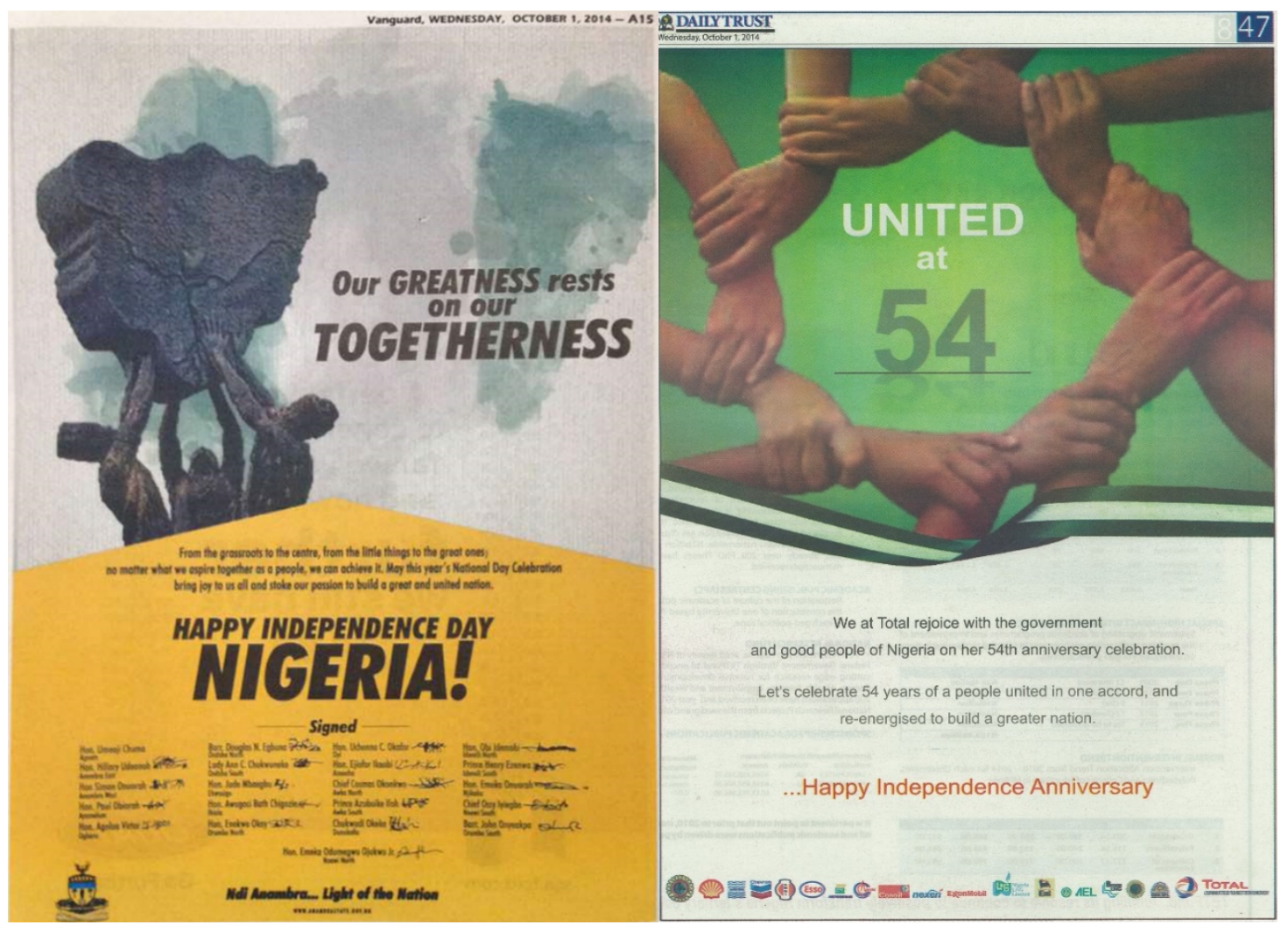

FIGURE 3. Images reproducing the ideology of unity through diversity (Left: Vanguard, Oct. 1, 2014, p. A15. Right: Daily Trust, Oct. 1, 2014, p. 47)

\section{NATION BUILDING}

The construction of unity through nation building is also identified as an essential dominant theme in the NCAs. The idea of nation building appeared to have been conceived by the producers of the texts to be a unitary factor capable of holding a country together against any possible disintegration (Haag, 2010, p. 346). In the visual plate on the left hand side in Figure 4 , the concept of unity through nation building is reproduced, naturalised and normalised through metaphorical representation and abstraction. Nations could be depicted in complete abstraction and symbolism when discourses related to their existential problems are recontextualised (Machin, 2013, p. 353). The social actor, the nation, Nigeria, with all its complexities, is reproduced as a rising sun at dawn in the shape of Nigerian map. By recontextualising the social events, the representative rising sun in the open horizon is abstracted to give an optimistic impression of a bright new era in the history of nation, full of limitless potential. The discursive process in Figure 4 seemed to have been infused with some folkloric touches of nation's destiny and homeland as symbolised by the rising sun, the shores, and the open sea. Substituting the nation with a bright rising sun at dawn suggests some sort of solidity and timelessness of purpose. It also supposed to normalise the idea of the country aiming to rise to the highest point of growth and development in the face of prevailing issues threatening its unity and corporate existence as a united nation (Machin, 2013, pp. 352-353). Inside the visual frame, images of a rising sun on the horizon, an open blue sky, a sea, and shore are depicted. The image of the rising sun, as designed in the shape of Nigerian Map, is a 
recontextualisation of the Nigerian current situation in an attempt to normalise, naturalise and reproduce the discourse of unity through nation building and the hope for a new dawn in the horizon for the country (Kress \& van Leeuwen, 2006).

The visual image on the right hand side in Figure 4 presents the discursive recontextualisation of the social actors and events, which is targeted at normalising and reproducing unity discourse as the major instrument for realising progress and national development. The social participants and events are metaphorically represented in total abstraction. Abstracting or generalising is suggested when analysing certain details and complexities in discourses associated with critical national issues. For example, the representational essence of unity and togetherness as the mechanism for progress is symbolically reproduced by way of a large collection of interlocking cogwheels. Bounded by a single chain, these numerous cogwheels, which come in different specifications in terms of sizes, shapes and colours, were organised in the shape of the Nigerian Map bounded by the chain. The social participants in this symbolic process of moving one another, as it is obtained literally in the case of the actual cogwheels, have been substituted through functionalisation. In doing so, the idea of attaining any progress appeared to have been linked to unity and togetherness, as depicted in the symbolic functions of the cogwheels, which has been metaphorically attributed to the recontextualised social actors and events. Abstracting the discursive interaction in Figure 4 involves the exclusion of virtually most of the social relations and the real production processes involved. For example, the human factor and the procedures with which these cogwheels are arranged in the shape of Nigerian Map have not been revealed. Instead, it is the end-result of that presumed depictive organisation that is foregrounded, where numerous cogwheels of different sizes and colours, bounded in the shape of the Nigerian Map are portrayed.

The feature in the discursive process in Figure 4 includes the chain, with which all the cogwheels were confined into one entity. The chain may have been attached to secure the borders to explain and normalise the symbolic concurrent movements triggered by the series of teeth edges of the numerous cogwheels fitting into one another. This symbolism may be suggestive of unity of purpose as well as putting all hands on the same deck to keep the nation moving in the right direction. The producers of the text in Figure 4 seemed to have removed any reminders of the prevailing regional, ethnic, or religious biases from the discursive process. However, there are faint human resonances: four of the cogwheels have longitudinal lower holes with regular higher ones, resembling iconic smiley faces. Moreover, the political boundaries technically separating Nigeria's 36 states from one another appeared to have been taken away from the interaction (Machin, 2013). 


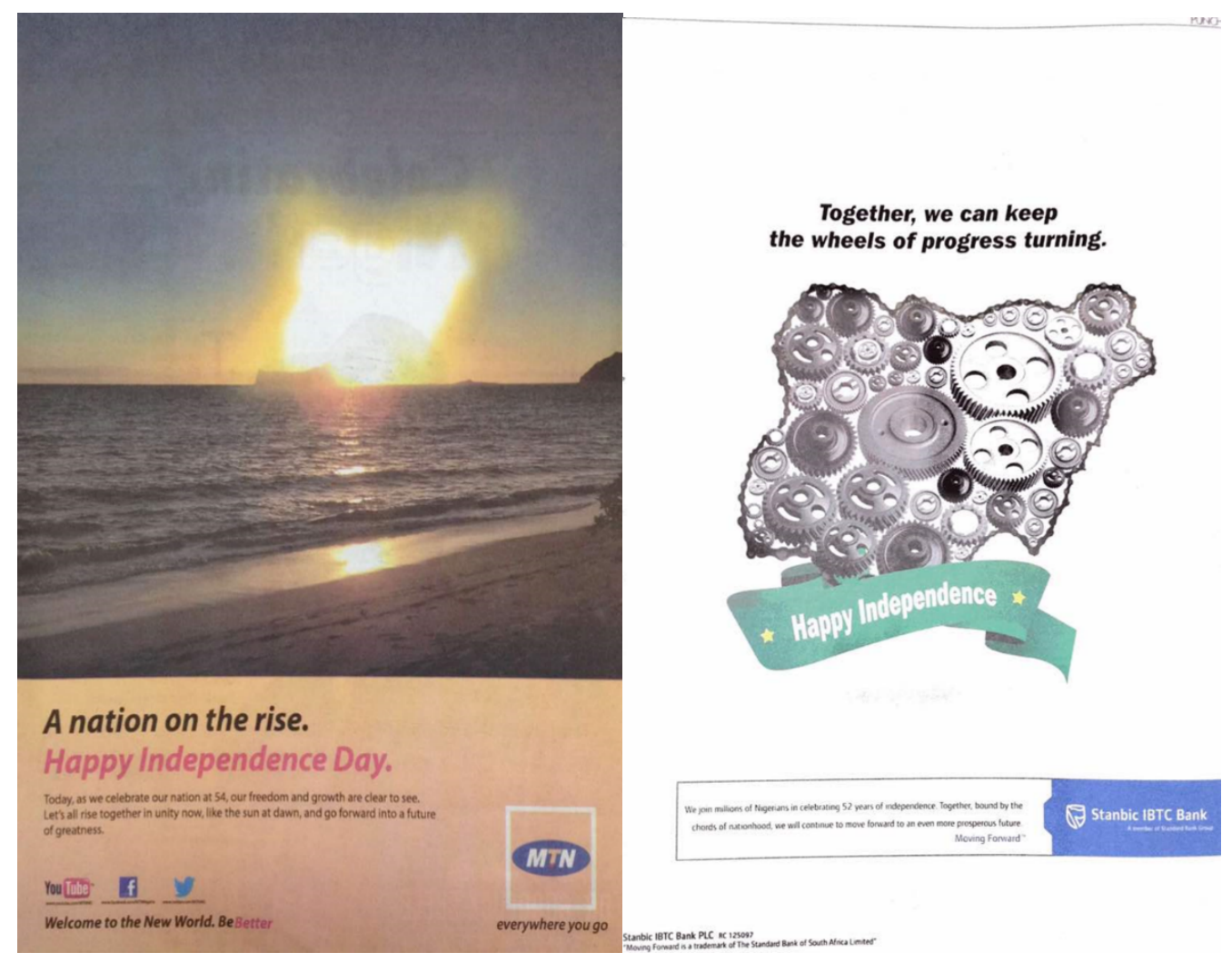

FIGURE 4. Reproduction of nation building as a tool for realising national unity (Left: Vanguard, October 1, 2014. Right: Punch, October 1, 2012)

\section{CULTURAL DIVERSITY}

The notion of cultural diversity is another prevailing theme in the NCAs found to be so contributory when it comes to the construction of unity in the Nigerian context. With the two concepts mostly used interchangeably, the idea of cultural diversity is believed to have been originated from that of multiculturalism (Haag, 2010, pp. 333-337), with the latter dominating most discussions on the former. It is argued that the concept of cultural diversity is believed to have been mostly focused on cultural origin, while other categories, which include gender, race, age or sexuality, are virtually left out. Thus, multiculturalism, then, is basically targeted at forging cultural diversity (Haag, 2010, pp. 333-337). In Figure 5, the social actors in the visual plate on the left hand side are represented in three different attires, which is intended to symbolise the three major ethnic groupings in Nigeria that include: the Yorubas, the Hausa/Fulanis and the Igbos. The written expression: let's celebrate our uniqueness as a people... we celebrate the spirit of unity in diversity amongst us seemed to have been metaphorically manifested in the recontextualised actions of the represented participants by way of smiling, having a good time and chanting a particular song or slogan all at the same time. This is another discursive strategy of naturalising and reproducing the concept of cultural integration and unity of purpose among people of diverse ethnic and religious backgrounds, as in the case with the status quo in Nigeria. Moreover, the discourse of cultural diversity appears to have also drawn from a commercial discourse. Through textual hybridity a number of discourses are usually made to play out within a communicative event so that specific interests would be privileged or served.

In the visual plate on the right hand side in Figure 5, the symbolic concept of unity through cultural diversity and the social actors are presented in total abstraction, where the action and the participants are represented by their functions or what they could easily be 
identified with (Machin, 2013). For example, the representational concept of unity through cultural diversity in Figure 4 is completely recontextualised with a whole range of local or traditional musical instruments displayed in the absence of the real people playing such instruments. The strategy of invoking presumed melody and dancing seems to have been added to naturalise and communicate the message in fashion. In addition, the producers of the text appeared to have given enough white spaces in between the musical instruments, as they are positioned on the borderline. This, according to Machin (2013), may have been deliberately done to create some virtual sense of simplicity and a space for breathing in an attempt to naturalise and normalise the discourse of cultural diversity through fashioning (Machin, 2013, p. 348). The written expression: celebrating 55 years of Nigeria's Independence, which occupies the Ideal position on the upper part, is said to be standing for the key message and is referred to as the Announcement in the plate. Under this verbal expression, a visual image composed of the Nigerian map, demarcated with an assortment of musical instruments placed on the borderline, is positioned in the middle of the plate. The Centre spatial dimension occupied by the visual participants in Figure 5 appears to be the prime communicator and the central point of information in the composition, most especially with the absence of other information distributed to the plate margins (Kress \& van Leeuwen, 2006).

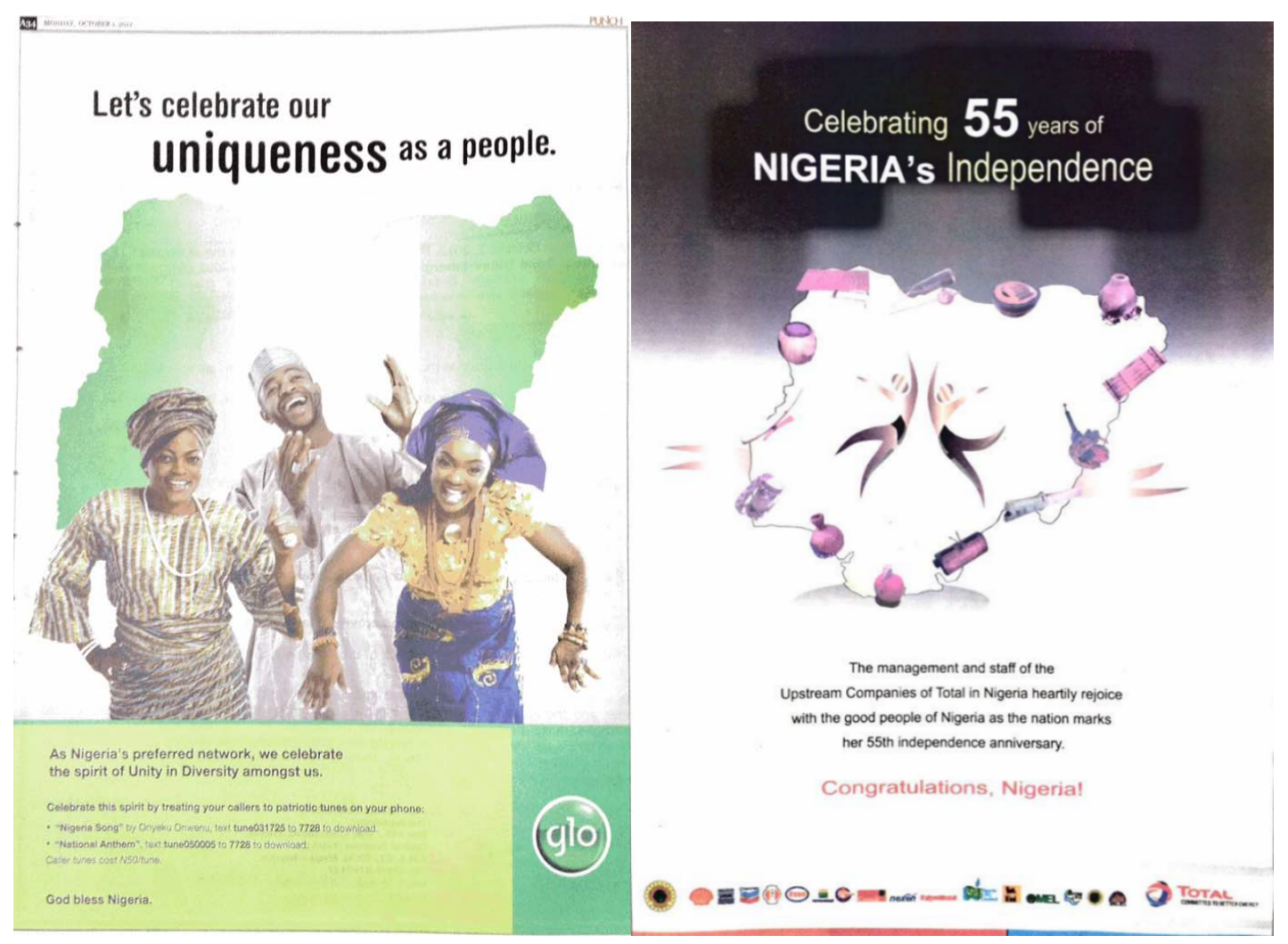

FIGURE 5. Re-enactment of cultural diversity as a vehicle for consolidating national unity (Left: Punch, October 1, 2012, p. A34. Right: The Guardian, October 1. 2015, p. 41)

The following tables present the detailed strategic realisations construed out of the visual devices and spatial dimensions of the participants in the NCAs. The meaning-making process is related to the identified recurrent themes as well as the pseudo-patriotic construction of the unity discourse as envisioned and designed by the sponsors of the NCAs analysed in this study. The summary covers Figures 1 to 5 respectively. 
TABLE 2. Summary of Visual Realisations in NCAs/Representational Structure

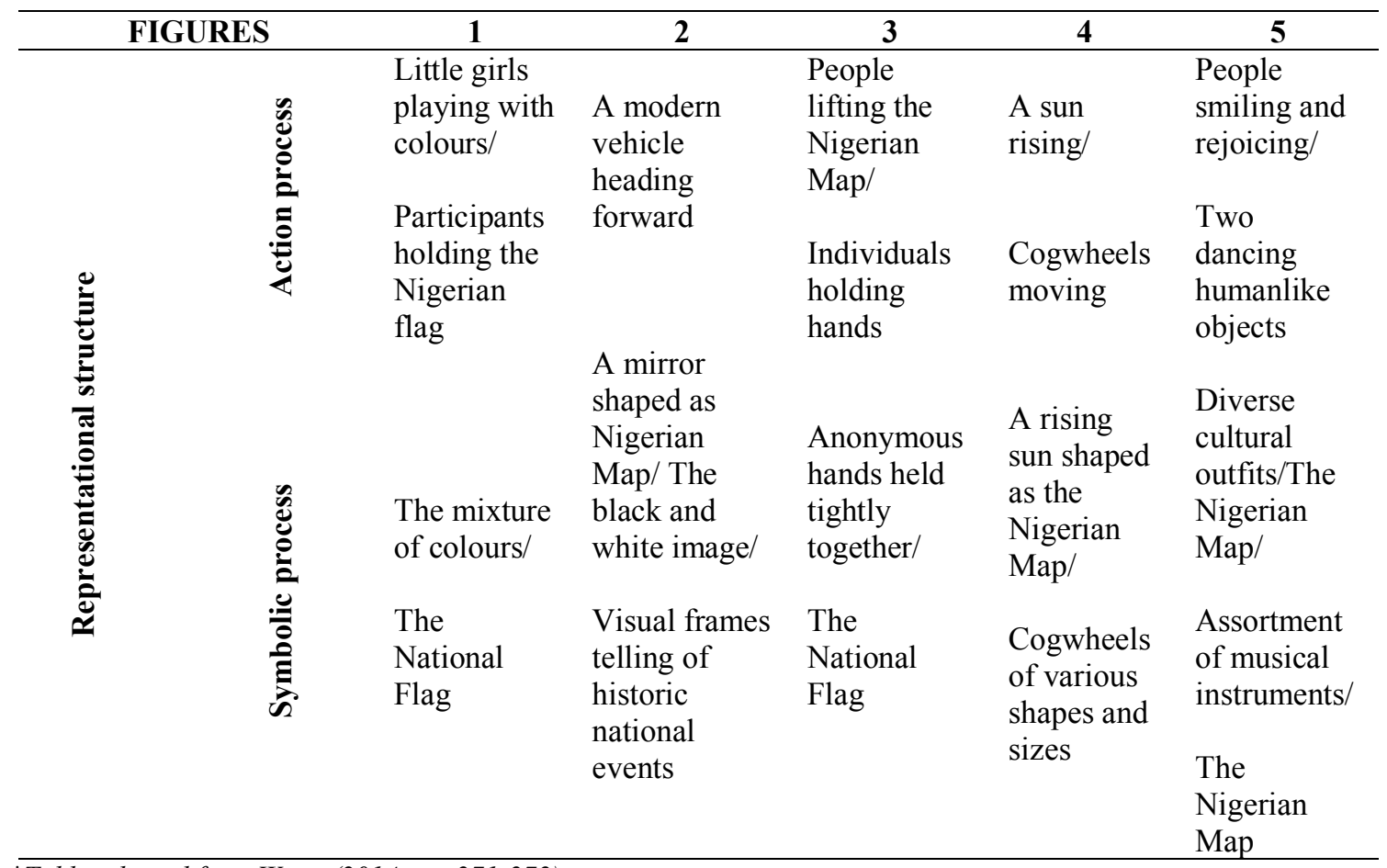

Table 2 summarises the visual realisations construed from the representational structure of the participants in the NCAs used for this study. Representational meaning stands for the ability of any semiotic system(s) to represent segments of the practical world outside its particular systems of linguistic codes. The process could be either referentially or pseudoreferentially. In other words, language involves representations and constructions of people's reality, where various types of participants are incorporated. According to VG, representational meaning is sub-divided into two categories, that is: the narrative and conceptual processes of meaning-making (Kress \& van Leeuwen, 2006; Liu, 2019).

TABLE 3. Summary of Visual Realisations in NCAs/Interactional Meaning

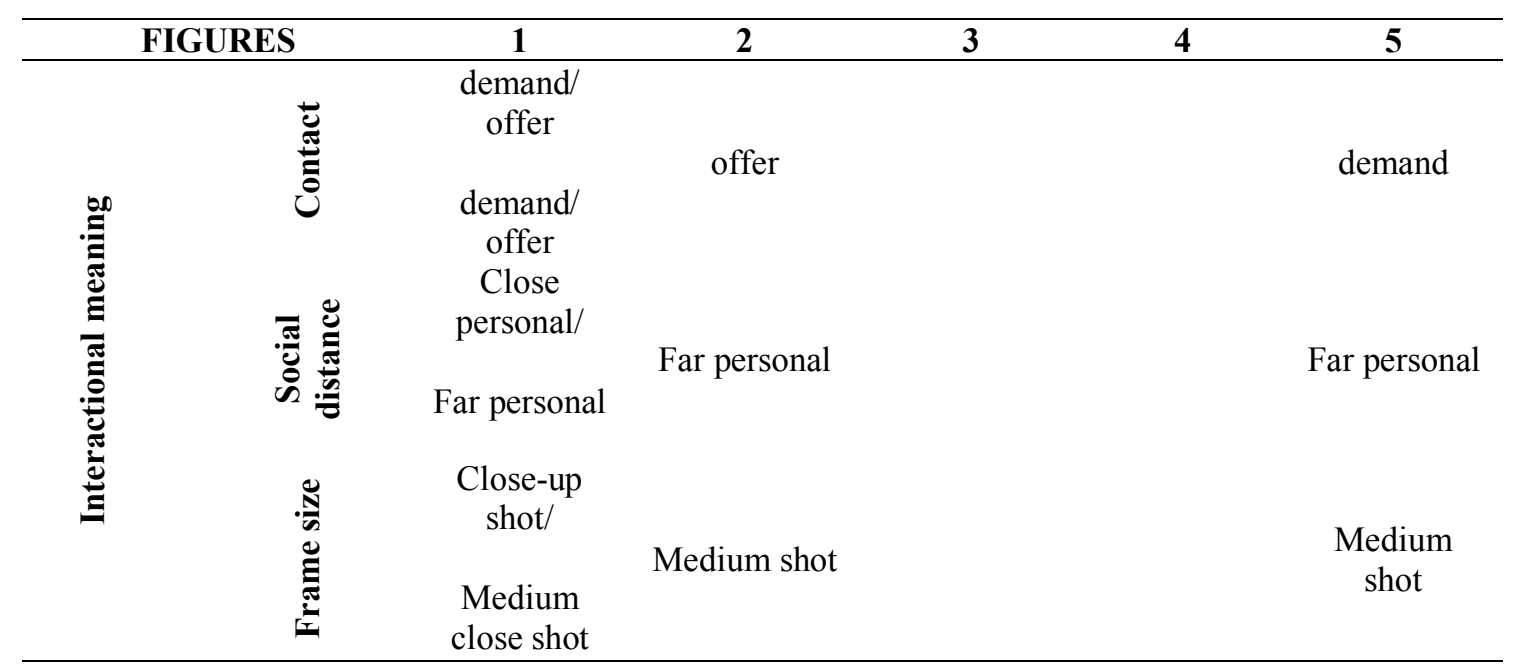




\begin{tabular}{llllll}
\hline & high/ & High/ & high/ & high/ \\
& high & Low & high & high & high \\
\hline
\end{tabular}

*Table adapted from Wang (2014, pp. 271-272)

Table 3 summarises the visual realisations made out of the interactions of the participants in the NCAs analysed. This is the interactional meaning, the second metafunction of language proposed by the VG. Interactive meaning signifies the ability of any semiotic component to demonstrate the social relations realised between the represented producer(s) of a code, the represented viewer(s) and the represented object(s) involved (Kress \& van Leeuwen, 2006; Wang, 2014; Liu, 2019).

TABLE 4. Summary of Visual Realisations in NCAs/Compositional System

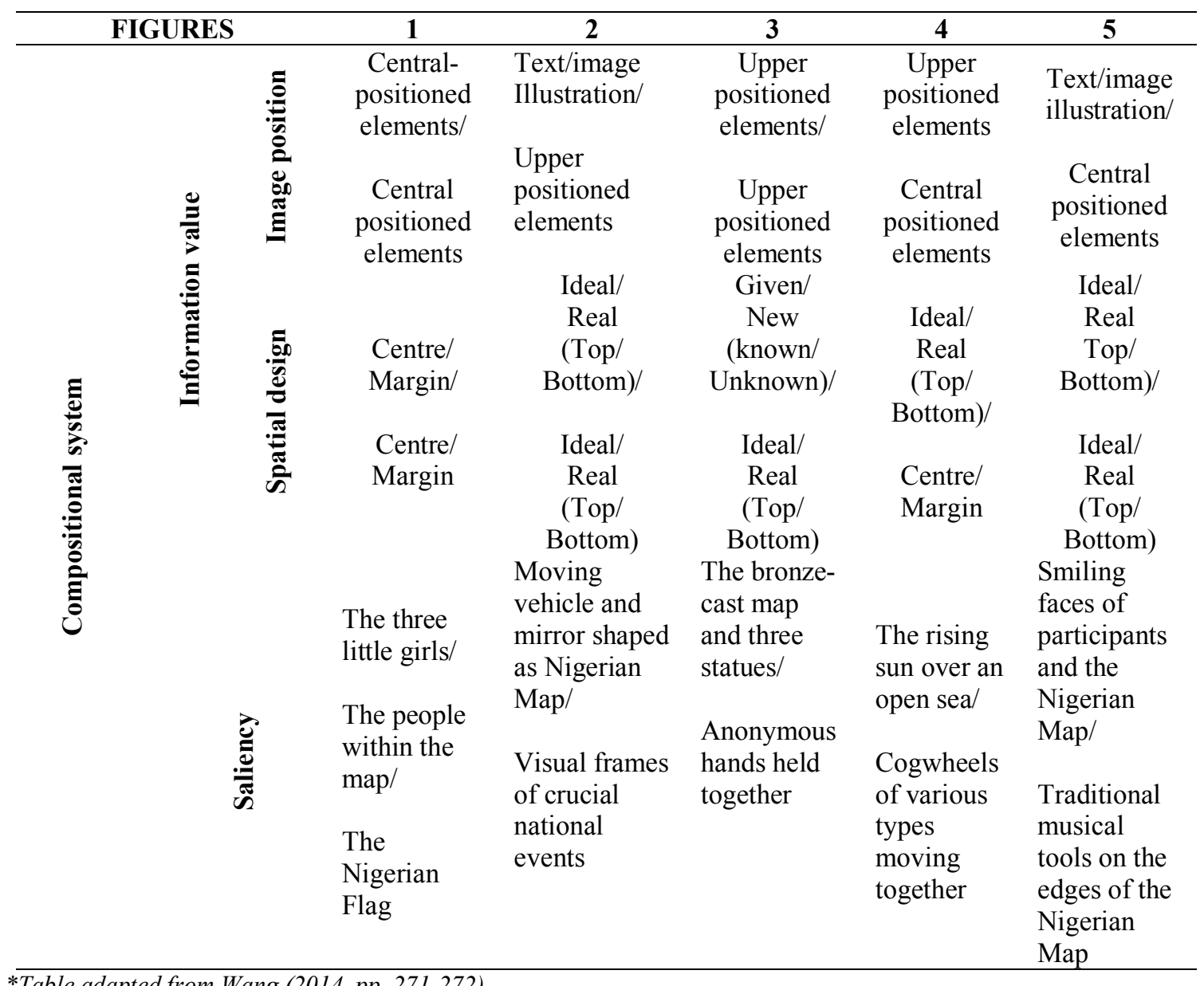

*Table adapted from Wang (2014, pp. 271-272)

Table 4 summarises the visual devices and the spatial dimensions as obtained in the compositional structure of the NCAs analysed in this study. Compositional meaning implies the internal capacity of any semiotic components to construct variety of texts as well as complex linguistic codes that would fit together in and for the contexts which they were meant. In this sense, a multimodal text could be taken as a compositional entity, for instance (Kress \& van Leeuwen, 2006; Wang, 2014; Liu, 2019). 


\section{CONCLUSIONS}

This article is focused on the discursive recontextualisation of the problem of unity within ethnically diverse Nigeria, as it is re-enacted and communicated through privately sponsored NCAs. Special attention is paid to the discursive actions believed to have been performed in the name of promoting unity by the principals of the NCAs to further opportunistic objectives. Drawing from the QCA, the AST (McCombs \& Shaw, 1972), the MCDA (Wang, 2014; Machin \& Mayr, 2012; Machin, 2013) and the VG (Kress \& van Leeuwen, 2006), the analysis revealed how multisemiotic linguistic resources and other discursive strategies have been employed to manipulate texts to control the discourse and promote the type of national unity envisioned by the sponsors of the NCAs. The QCA employed has identified five recurrent themes dominating the NCAs discourse. The analysis found that the type of unity envisaged by the private principals of the NCAs apparently runs contrary to the actual state of the nation, the common perception of ordinary Nigerians and many people's lived experiences.

Intertextually, the analysis revealed how unity discourse is tied to other discourses thus representing pseudo-patriotism, commercialisation, and corporate social responsibility (Yusuf, 2008). Specifically, through pseudo acts, the outwardly profit-oriented sponsors of the NCAs seemed to exploit the existing fragile state of unity in favour of their 'capitalistic enterprises' through participating in mainstream national issues of their host communities. Somehow, they appeared to use these pseudo practices to upgrade their company profiles, solidify their customer base as well as improve their corporate image in the 'eyes' of both the authorities and the general public (Alkatiri, 2014, p. 168). The findings of the present article may upgrade people's understanding of the way private individuals and corporate organisations influence media coverage of events with the intent of manipulating discourses and social practices in order to realize further ideological or commercial purposes (Fairclough, 1995). This article recommends that further research could investigate the discursive representations of unity through other semiotic resources in different contexts. Such resources may include statues, monuments, and other prominent national symbols in order to ascertain possible manifestations of discursive manipulation and realisation of vested interests by government or private individuals and organisations through such representations.

\section{REFERENCES}

Abousnnouga, G., \& Machin, D. (2010a). Analysing the language of war monuments. Visual Communication. Vol. 9(2), 131-149. doi: 10.1177/1470357210369884

Abousnnouga, G., \& Machin, D. (2010b). War monuments and the changing discourses of nation and soldiery. In A. Jaworski \& C. Thurlow (Eds.), Semiotic Landscapes: Language, Image, Space (pp. 219-240). Continuum.

Adediji, A. (2016). The Politicisation of Ethnicity as Source of Conflict: The Nigerian Situation. Köln, Deutschland: Springer VS. doi: 10.1007/978-3-658-134839

Ademilokun, M., \& Taiwo, R. (2013). Discursive strategies in newspaper campaign advertisements for Nigeria's 2011 elections. Discourse \& Communication. Vol. 7(4), 435-455. doi: 10.1177/1750481313494501

Ahmad Tajuddin, S. N. A. (2017). Framing in strategic communications: The construction of 'national unity' through Public Service Announcements (PSAs) in Malaysia. Unpublished Ph.D thesis, The University of Queensland, Australia.

Alkatiri, Z. (2014). Pseudo nationalism of the commercial companies on the commemoration of Indonesian national holidays through non-commercial advertising in print media in the years of 1980 to 2008. Advances in Historical Studies, 3, 155-169. Retrieved from http://dx.doi.org/10.4236/ahs.2014.33014 
Alkhammash, R. (2020). Discursive Representation of the EU in Brexit-related British Media. GEMA Online ${ }^{\circledR}$ Journal of Language Studies. Vol. 20(1), 77-91. http://doi.org/10.17576/gema-2020-2001-05

Anyebe, A. A. (2017). A reflection on ethnic militia in Nigeria. International Journal of Development and Sustainability. Vol. 6(9), 972-983. Retrieved from https://isdsnet.com/ijds-v6n9-03.pdf

Babatope, J. K. (2017). Language and national security: A linguistic study of President Muhammadu Buhari's broadcast on the unity of Nigeria. International Journal of Humanities and Social Science Invention (IJHSSI). Vol. 6(11), 23-28.

Bourne, R. (2015). Nigeria: A New History of a Turbulent Century. Zed Books Limited. Commemorating the Merdeka spirit of unity. (2010, September 1). Retrieved August 13, 2020 from https:/www.theedgemarkets.com/article/commemorating-merdekaspirit-unity

Emmanuel, M. (2016). Federalism in Nigeria: Between Divisions in Conflict and Stability in Diversity. Globethics.net International Secretariat.

Fairclough, N. (1995). Media Discourse. London: Edward Arnold.

Falola, T., \& Heaton, M. M. (2008). A History of Nigeria. Cambridge University Press.

Haag, O. (2010). 'You Are Germany' - 'I Am Australian': The construction of national unity through diversity in select examples from Australia and Germany. National Identities. Vol. 12(4), 333-349. doi: 10.1080/14608944.2010.520968

Holman, J., \& Arunachalam, D. (2015). Representing harmony and diversity: Media representations of multiculturalism and ethnicity in Singapore. Asian Ethnicity. Vol. 16(4), 498-515. doi: 10.1080/14631369.2015.1062070

Jibril, A. T., Mohamad Ali, A., Kasim, Z. M., \& Yuit, C. M. (2015). Communicating beyond the conventional functions: An assessment of newspaper announcements. Online Journal of Communication and Media Technologies. Vol. 5(2), 41-60.

Jibril, A. T. (2018). Discursive construction of national unity in Nigerian newspaper congratulatory announcements. Unpublished Ph.D. thesis, Universiti Putra Malaysia, Selangor, Malaysia.

Koch, N. (2019). The corporate production of nationalism. Antipode. 1-21. doi: 10.1111/anti.12588

Kress, G., \& van Leeuwen, T. (2006). Reading Images: The Grammar of Visual Design (2 ${ }^{\text {nd }}$ edition). Routledge.

Liu, S. (2019). A Multimodal Discourse Analysis of the Interactive Meaning in Public Service Advertisement. Journal of Advances in Linguistics, 10, 2348-3024. 10.24297/jal.v10i0.8196

Machin, D. (2013). What is multimodal critical discourse studies? Critical Discourse Studies. Vol. 10(4), 347-355. doi: 10.1080/17405904.2013.813770

Machin, D., \& Mayr, A. (2012). How to Do Critical Discourse Analysis: A Multimodal Introduction. Sage Publications.

McCombs, M., \& Valenzuela, S. (2007). The agenda-setting theory. Cuadernos de Información. Vol (20), 44-50.

McCombs, M. E., \& Shaw, D. L. (1972). The agenda-setting function of mass media. The Public Opinion Quarterly. Vol. 36(2), 176-187. Oxford University Press. Retrieved from http://dx.doi.org/10.1086/267990

Mohamed Salleh, S. (2013). Unity in diversity: Inculcating the concept of 1Malaysia through local television programmes. Journal of Asian Pacific Communication. Vol. 23(2), 183195. doi: 10.1075/japc.23.2.01moh

Monguno, A. K., \& Bagu, C. (2017). The geographical and historical phases of the Boko Haram insurgency in Nigeria. In J. Ibrahim, C. Bagu \& Y. Z. Ya'u (Eds.), Understanding 
Community Resilience in the Context of Boko Haram Insurgency in Nigeria (pp. 3354). Centre for Information Technology and Development (CITAD).

Odeyemi, J. O. (2014). A political history of Nigeria and the crisis of ethnicity in nationbuilding. International Journal of Developing Societies. Vol. 3(1), 87-95. doi: $10.11634 / 216817831403459$

Onimisi, T. (2015). The prognoses of the 2011 electoral violence in Nigeria and the lessons for the future. Mediterranean Journal of Social Sciences. Vol. 6(1)S1. doi: $10.5901 / \mathrm{mjss} .2015$.

Solomon, H. (2015). Terrorism and Counter-Terrorism in Africa: Fighting Insurgency from Al Shabaab, Ansar Dine and Boko Haram. Palgrave Macmillan.

Stögner, K., \& Wodak, R. (2016). The man who hated Britain: The discursive construction of 'national unity' in the Daily Mail. Critical Discourse Studies. Vol. 13(2), 193-209. doi: 10.1080/17405904.2015.1103764

Suppiah, P. C., Kaur, S., Arumugam, N., \& Shanthi, A. (2019). News coverage of foreign sex workers in Malaysia: A critical analysis. GEMA Online ${ }^{\circledR}$ Journal of Language Studies. Vol. 19(1), 136-152. http://doi.org/10.17576/gema-2019-1901-08

Wang, J. (2014). Criticising images: Critical discourse analysis of visual semiosis in picture news. Critical Arts: South-North Cultural and Media Studies. Vol. 28(2), 264-286. doi: 10.1080/02560046.2014.906344

Wida, E. C. (2019, August 23). This beautiful Cadbury bar has 4 different types of chocolate. Retrieved August 13, 2020 from https://www.today.com/food/cadbury-trying-spreadawareness-about-racism-chocolate-t161192

Wok, S., \& Mohamed, S. (2017). Internet and social media in Malaysia: Development, challenges and potentials. In B. Peña Acuña (Ed.), The Evolution of Media Communication (pp. 45-64). InTech.

Yusuf, H. O. (2008). Oil on troubled waters: Multinational corporations and realising human rights in the developing world, with specific reference to Nigeria. African Human Rights Law Journal. Vol. 8, 79-107. 


\section{ABOUT THE AUTHORS}

Ahmed Tanimu Jibril is currently with the Department of English and Literary Studies, Bauchi State University, Gadau, Nigeria. His research focus is within the multimodal critical discourse analysis, the application of visual grammar on multimodal texts and a considerable interest in the relationship between language and the media. ahmedtanimu76@gmail.com

Afida Mohamad Ali is an Associate Professor attached to the Department of English, Faculty of Modern Languages and Communication, Universiti Putra Malaysia (UPM). Her research interests are mainly in the areas of LSP/ESP, corpus linguistics, and genre analysis, specifically genres used in professional settings i.e. business, finance, health, tourism and the new media.

Zalina Mohamad Kasim is an Associate Professor at the English Language Department, Faculty of Modern Languages and Communication, Universiti Putra Malaysia. She received a Master's degree in Linguistics from Malaya University and later obtained a PhD degree from the Lancaster University in 2007 in Linguistics. Her research interests are mainly related to the field of cognitive stylistics and discourse studies. Currently she is working on metaphors in media and political discourses.

Chan Mei Yuit is an Associate Professor at the Department of English, Universiti Putra Malaysia. She specializes in the areas of applied linguistics, discourse and communication studies, language learning and acquisition as well as LSP. Her research interests are predominantly in the areas of institutional and professional discourse practices, language and cognition, health communication and discourses of indigenous communities. 